DOI: https://doi.org/10.32839/2304-5809/2021-7-95-17

УДК 811.111’37

Павлович T.I. ${ }^{1}$, Суродейкіна T.В. ${ }^{2}$, Швигар Д.М.

Чернівецький національний університет імені Юрія Федьковича

\title{
ОСОБЛИВОСТІ ІСТОРИЗМІВ ТА ЛЕКСИЧНИХ АРХАЇЗМІВ У ТВОРЧОСТІ Г. ЛАВКРАФТА
}

Анотація. Подана стаття присвячена дослідженню історизмів і лексичних архаїзмів у творчості Говарда Лавкрафта. Автором використано історизми на позначення старовинних мір виміру, професій та роду занять, соціального стану, географічних назв, назв зниклих народів та племен, обрядів та свят, приладів, які вийшли з ужитку, релігійних організацій, назв вимерлих тварин. Серед них переважають назви зниклих племен північно-американських індіанців, які слугують історичним тлом для написання оповідань. Також нами було виявлено власне лексичні архаїзми, витіснені з мови синонімічними номенами. Лексико-словотворчі архаїзми в проаналізованих творах Г. Лавкрафта відрізняються від сучасних відповідників вживанням інакшого суфіксу. Лексико-фонетичні архаїзми мають дещо відмінне звукове оформлення кореня порівняно із сучасною літературною мовою. Лексико-семантичні архаїзми у своїй семантичній структурі містять як активно вживані в сучасній англійській літературній мові значення, так і застарілі. Ключові слова: Говард Лавкрафрт, архаїзми, історизми, перекладацькі техніки, застаріле значення.

Pavlovych Tetiana, Surodeikina Tetiana, Shvyhar Diana Chernivtsi National University named after Yurii Fedkovych

\section{PECULIARITIES OF OBSOLETE AND ARCHAIC WORDS IN THE STORIES BY H. LOVECRAFT}

Summary. A large scientific interest in investigating archaic and obsolete vocabulary may be explained by its temporal stylistic colouring and its wide use for conveying cultural-biased vocabulary in historical novels. Thus, the study of its lexical and semantic peculiarities stipulates the topicality of our research. It aims at a thorough investigation of lexical and semantic characteristics of the archaic vocabulary selected from the works of Howard Lovecraft. The data of our investigation is presented by a corpus of 153 archaic lexemes selected from the works by H. Lovecraft containing 70652 words (212 pages). The scientific novelty of the paper lies in the complex approach to the study of archaic vocabulary as its lexical and semantic characteristics have not been revealed yet. Archaisms are defined as obsolete objects and phenomena that came out of use. Archaic words are mostly employed with a stylistic purpose. In the process of our analysis, we have found out that the author employed a range of obsolete words denoting measures, jobs, social status, geographical names, names of disappeared peoples and tribes, obsolete equipment, religious organisations, and extinct animals. Among them, those designating former North American tribes are prevailing serving as a background for the stories under investigation. We have also traced lexical archaic words squeezed out of the language by their contemporary synonyms. Another group, lexical word formative archaic words, differs from their present forms in the use of another suffix. Lexical phonetic ones vary in their sound form, while the structure of lexical-semantic ones contains both actively used and obsolete meanings. The study has shown that in the majority they convey their contemporary meanings, though a third of them make use of archaic ones as well. The outcomes of our quantitative analysis have proved that the data under study have the following correlation: a third of all the archaic lexemes are obsolete, a fifth is represented by lexical-semantic ones with the lexical phonetic being the least frequently used. Lexical archaic words proper and lexical word formative comprise about a tenth of the total number of examples.

Keywords: Howard Lovecraft, archaic words, obsolete words, translation techniques, obsolete meaning.

Постановка проблеми. Серед лексичних елементів сучасної англійської мови, семантична структура яких володіе певною часовою маркованістю, досліджуються архаїзми. Зацікавленість у такому дослідженні пояснюеться iï широкою вжкваністю письменниками для передачі культурного колориту в історичних романах. Отже, для цього їм може стати у нагоді вивчення лексико-семантичної структури архаїзмів, що і становить актуальність обраної теми.

Аналіз останніх досліджень i публікацій. До аналізу лексики художніх творів звертались І.К. Білодід, П.І. Горецький, П.П. Доценко, В.С. Ільїн, Г.П. Іжакевич та багато інших дослідників. Привертае увагу також дослідження О. Коваленка та Т. Малика, в якому викладено свіжі погляди на архаїчну лексику, подано нетрадиційну класифрікацію застарілих слів, а також аналізуеться взаємозв'язок архаїзмів, діалектизмів і поетизмів на прикладі історичних романів В. Скотта. Л. Мельник і Т. Ласінська описують особливості перекладу архаїзмів українською та англійською мовами.

Виділення не вирішених раніше частин загальної проблеми. Дослідженню характерних особливостей творчості Г. Лавкрафта була присвячена низка досліджень. Так, А.В. Васильченко та О.Я. Кресан розглядали емоційносмислову домінанту в його творах, Д.Д. Денисова аналізувала його внесок у розвиток традиції weird fiction в англомовній літературі, O.O. Нагачевська досліджувала трансформацію готичної

${ }^{1}$ ORCID: https://orcid.org/0000-0003-2483-6390

2 ORCID: https://orcid.org/0000-0002-3862-5677 
традиції у доробку Г. Лавкрафта, Н. Годраті описував еволюцію жанру «лавкрафртівський хорор».

Як бачимо, комплексний підхід до вивчення архаїчної лексики у творчості Г. Лавкрафрта ще не застосовувався, її лексико-семантичні характеристики на матеріалі його творів не були розкриті. У цьому ми вбачаємо новизну нашого дослідження.

Мета роботи полягає в аналізі лексико-семантичних характеристик архаїчної лексики в в творчості Г. Лавкрафрта.

Виклад основного матеріалу. Для детального вивчення архаїчної лексики у творчому доробку Говарда Лавкрафрта, ми дослідили наступні його оповідання та повісті: The Call of Cthulhu, The Dunwich Horror, Whisperer in the Darkness, The Dreams in the Witch House загальним обсягом 212 сторінок, або 70652 слововживання. 3 них ми виписали історизми та архаїзми, детально проаналізовані нижче. Для визначення наявності в них архаїчного значення, кожна лексема та конструкція була ретельно перевірена за тлумачним англомовним словником Collins Dictionary, який маркуе такі одинищі як archaic або obsolete.

Розглянемо спочатку історизми (18 прикладів у 49 слововживаннях).

За класифрікацією I. Білодіда [1], розділимо історизми, вилучені нами з проаналізованих творів Г. Лавкрафрта на наступні семантичні групи: - старовинні міри виміру:

"After vigintillions of years great Cthulhu was loose again, and ravening for delight» [5].

"Після десятків мільйонів років Великий Ктулху знову був вільний $і$ жадав втіхи" [2].

«1. US and British a large number equal to $10^{63:}$ 2. a large number equal to $10^{120}$ in older British English and Latin American countries» [4].

- професії та рід занять, 7 разів зустрічаеться в оповіданні The Call of Cthulhu у вигляді лексеми squatter, наприклад:

"...hung, head downward, the oddly marred bodies of the helpless squatters who had disappeared" [5].

"...звисали донизу головою дивовижно спотворені тіла зниклих скватерів" [2].

За визначенням словника Словопедія, скватер має значення «фберлер-колоніст, шо зайняв вільну, необроблену ділянку зеллі при колонізацӥ в США, Канаді, Австралї̈ і Новій Зеландїі» [3].

У тлумачному словнику англійської мови Collins Dictionary зустрічаємо наступні визначення squatter, два з яких підтверджують українську дефініцію:

«1. a person who occupies property or land to which he or she has no legal title; 2. (in Australia) a. (formerly) a person who occupied a tract of land, esp. pastoral land, as tenant of the Crown; b. a farmer of sheep or cattle on a large scale; 3. a 19th-century settler who took up large acreage on a Crown lease» [4].

- соціальний стан передано архаїчними лексемами armigerous families - дворянські сіл'ї, які мали герб на прапорі, та squire - сквайр в повісті The Dunwich Horror, наприклад:

"The old gentry, representing the two or three armigerous families which came from Salem in $1692 . . . \prime[5]$.
"Стара аристократія, яку представляють два чи три гербоносні роди, що приїхали із $\mathbf{C a}$ лела 1692 року" [2].

«of, having, or entitled to have a coat of arms» [5].

"In 1917 the war came, and Squire Sawyer Whateley, as chairman of the local draft board..." [5]. «У 1917 році прийшла війна, i сквайр Сойєр Уотлі, як голова лісиевої призовноӥ колісї..." [2].

У давнину сквайром називали найбільшого землевласника в окрузі.

- географічні назви: Salem 3 прикладу вище, містечко, в якому відбулася страта відьом у 1692 році, римська назва Шотландії - Caledonia та уявна країна фрей - faery :

"... and a third centring in the Passumpsic in Caledonia County above Lyndonville» [5].

"а трете - у салому сериі Пассулпсика в окрузі Каледонія, шо вище Ліндонвіля» [2].

"... and around us stretched only the flowering waves of faery and the recaptured loveliness of vanished centuries - " [5].

"...а довкола воскресла краса минулих стоrimb..." [2].

Бачимо, що в останньому прикладі перекладач використав тактику вилучення, оскільки архаїчна лексема faery не перекладена і вилучена з тексту.

- назви зниклих народів та племен: Pocumtucks, Saracenic, Pennacooks, Hurons, men of the Five Nations, troglodytes and burrowers.

"...such spots were once the burial-places of the Pocumtucks..." [5].

"...у тих місиях колись були могильники покултуків" [2].

- назва зниклого у 18-му ст. племені Індіанців;

"... which have inherited many forms and traditions from the wizards of the Saracenic world [5].

"...успадкувати чилало чаклунських форлул від ворожбитів сарацинського світу" [2] .

- назва одного з числених арабських кочових племен, які мешкали на кордоні з Римською імперією та здійснювали на неї свої набіги.

"...knew the speech of all kinds of men Pennacooks, Hurons, men of the Five Nations - but did not seem to have or need any speech of their own" [5].

"знають мови різних народів - пеннакуків, гуронів, людей n'яти плелен, - але, найвірогідніше, своєї лови не лають, і складається враження, шо вона їл навіть не потрібна» [2].

Pennacooks - плем'я північно-американських індіанців, що мешкали на території сучасного штату Нью Гемпшир;

Huron - північно-американських індіанців, що мешкали на на захід від озера Гурон;

Ліга (конфредерація) ірокезів була відома в часи колонізації під назвою the Five Nations (Mohawk, Onondaga, Oneida, Cayuga, and Seneca). "... and gave to wild Wales and Ireland their dark hints of strange, small, and terrible hidden races of troglodytes and burrowers" [5].

«...нашептали напівдикил валлійиял та ірландиял про існування дивних, маленьких, моторошних і ретельно прихованих від людей плелен троглодитів і зеллериїв" [2].

- доісторичні мешканці печер.

- паганські обряди та свята, назви яких повторюються у кожному проаналізованому творі: May-Eve та Hallowmass (8 прикладів). 
"Through all the years Wilbur had treated his half-deformed albino mother with a growing contempt, finally forbidding her to go to the hills with him on May-Eve and Hallowmass..." [5].

«З плином часу Вілбур усе зневажливіше ставився до своєї матері-альбіноски, аж поки взагалі заборонив їй ходити з нили до пагорбів на Вальпургієву ніч і надвечір'я Дня всіх святих..." [2]

- група «прилади, які вийшли з ужитку" представлена лише в творі Whisperer in the Darkness архаїчними лексемами phonograph прилад для запису звуку, сучасним аналогом якого є диктофон, вжитою 9 разів, та словосполученням kodak pictures, також представленим 9 прикладами:

"It is here that we shall discuss them - you can see my phonograph on that corner stand" [5].

«Ось тут ми ще $і$ обговоримо, бачите мій gбонографб на поличиі у кутку?» [2].

"I've never dared shew the black stone or the kodak pictures, or play that record, to anybody but the ignorant peoplen [5].

"Я ніколи не наважувався нікому показувати ні чорний калінь, ні світлини, ніколи не давав прослухати той запис, за винятком простих неосвічених людей» [2].

Кодак - це бренд портативної фотокамери, розробленої Джорджем Істманом у 1888 р., єдиної існуючої на час написання повісті. Тому сучасне поняття фоотографрії постійно передається застарілим виразом kodak picture (view).

Варто відмітити, однак, що щі речі е застарілими лише 3 позиції сьогодення, а на момент написання твору вони знаходилися в активному вжитку.

- релігійні організації (конфесіі): Puritan - група англійських протестантів у 16-17 ст., які жили в дуже суворий релігійний спосіб:

"Perhaps the bulk of the Puritan settlers set them down bluntly as familiars of the devil..." [5].

«Переважна більшість пуритан пряло називала їх полічникали диявола..." [2].

- назви вимерлих тварин: saurians - ящери:

"The limbs, save for their black fur, roughly resembled the hind legs of prehistoric earth's giant saurians..." [5].

«Кіниівки, якщо не брати до уваги чорну шерсть, віддалено скидалися на задні лапи велетенських доісторичних ящерів..." [2].
3 наведених прикладів видно, що історизми в досліджених творах Г.Лавкрафрта розподілені за наступними семантичними групами: соціальний стан (2), прилади, що вийшли з ужитку (2), професії (1), обряди, свята (2), міри виміру (1), зниклі народи (7), вимерлі тварини (1), географрічні назви (3).

Зобразимо це за допомогою наступного рисунку 1:

3 рисунку видно, що чисельно переважають історизми з групи назв зниклих народів (36\%), переважно назв племен північно-американських індіанців, які слугують історичним тлом для написання оповідання або повісті. Решта груп представлені набагато меншою кількістю історизмів (5-16\%).

Власне лексичними архаїзмами називаємо застарілі слова, витіснені з мови синонімічними номенами, наприклад в оповіданні The Call of Cthulhu знаходимо наступні:

"...such eldritch contradictions of all matter, force, and cosmic order" [5].

«...такого моторошного заперечення салоі матерї̈, всіх фбізичних величин та космічного порядку" [2].

Згідно тлумачного словника англійської мови Collins Dictionary - це поетичне слово для вираження ознаки unearthly; weird [4].

У перекладі, однак, застосовано модуляцію значення і замість значення «дивний, позазелний» вжито лексему «моторошний», відбулося нівелювання архаїчного значення.

Дуже цікавою на наш погляд видаеться етимологія цього слова, яке походить від двох давньо англійських слів $\boldsymbol{c e l f}$ elf + rīce realm [4], тобто дослівно означае "з иарства ельббів".

Двічи зустрічається застаріла фраза на позначення прощання to bid adieu (to say goodbye):

That evening, after a day of hurried cabling and arranging, I bade my host adieu and took a train for San Francisco [5].

«Того ж вечора, після дня квапливої відправки телеграм і залагодження справ, я трохи заспокоӥвся і сів на потяг до Сан-Франииско" [2]..

У прикладі спостерігаємо вилучення архаїчного виразу та заміну його на зовсім інший «я трохи заспокоївся».

У наступному прикладі застаріла лексема bespeak з повісті The Dunwich Horror зараз передаеться сучасним синонімом show:

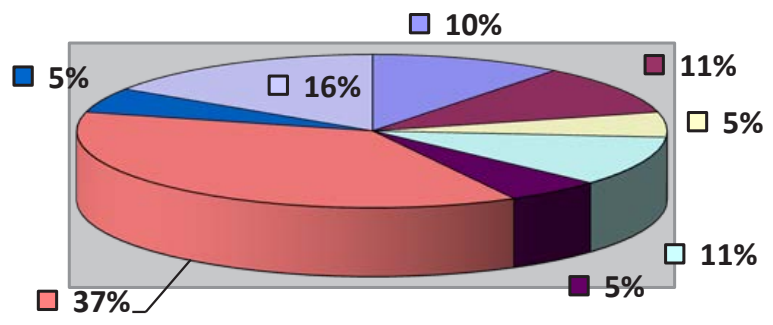

$\square$ соціальний стан
$\square$ прилади, що вийшли 3
ужитку
$\square$ професії
$\square$ обряди, свята
$\square$ міри виміру
$\square$ зниклі народи
$\square$ вимерлі тварини
$\square$ географічні назви

Рис. 1. Семантичні групи історизмів у творах Г. Лавкрафта 
"...wonders at the cluster of rotting gambrel roofs bespeaking an earlier architectural period than that of the neighbouring region" [5].

"...чудернацька купка ветхих халуп під мансардними дахали, вигляд яких свідчить про дуже давні архітектурні традищї, не характерні для інших споруд иього регіону" [2].

В українському перекладі знову відбулося нівелювання архаїчного значення.

У такий самий спосіб лексема архаїчна chamber має сучасний відповідник room:

"This chamber he lined with tall, firm shelving; along which he began gradually to arrange, in apparently careful order, all the rotting ancient books and parts of books..." [5].

«У иій кілнаті він поставив попід стінами високі дебелі полииі, на які поступово переносив, ретельно добираючи і впорядковуючи, всі ті зацвілі стародавні бболіанти та їхні частини..." [2].

Вкотре спостерігаємо нівелювання застарілого значення: chamber - кілнаті.

Наступне речення містить навіть два лексичних архаїзми, що надає йому пафосної атмосфрери (behold - see, smite - hit, kill):

"They bend the forest and crush the city, yet may not forest or city behold the hand that smites" [5].

"Вони згинають дерева у лісах і стирають на порох міста, хоча ні ліс, ані місто не бачать руки нишителя" [2].

Поряд із знову ж нівелюванням архаїчного значення (behold - бачать) використана граматична транспозиція, оскільки діеслово smites передано іменником нишителя. Таким чином, у тексті перекладу пафросна атмоссрера втрачається.

Особливої уваги заслуговуе лексичний архаїз beldame, який траплається п'ять разів у The Dreams in the Witch House. У тлумачному словнику наведено два його значення, обидва з яких вийшли з ужитку, перше - an old woman, esp an ugly or malicious one; hag - $€$ apхаїчним, а друге застаріле слово на позначення grandmother.

"The youth's oversensitive ears caught a hideous strangled cry, and presently the beldame came out of the room..." [3].

"Загострений слух юнака вловив якийсь здушений крик, а за лить стара повернулаcя..." [2].

"Sardonic, and seemingly unmotivated stare of the beldame had set him almost shivering especially the first time..." [5].

"У такі литі злостивий, уїдливий $i$ водночас байдужий погляд старої змушував його трелтіти, особливо під час першої зустрічі - " [2].

"He pulled the steel-like claws from his neck, and would have dragged the beldame over the edge of the gulf had not the claws received a fresh access of strength and closed in again" [5] .

«Волтер вивільнився від ї̈ хватки і майже встиг підтягти каргу до краю трикутного отвору, але до старої повернулися сили, $і$ вона знову вчепилася в його шию» [2].

Як видно з наведених речень, у них у всіх в оригіналі реалізуеться стилістично знижене архаїчне значення «карга, стара відьла», як зневажливе позначення старої жінки. Однак у тексті перекладу це значення збережене лише в останньому, а в перших двох архаїчне значення знівельоване (стара).
Останнім лексичним архаїзмом, вибраним нами 3 проаналізованих творів Г. Лавкрафрта, виявився прикметник infandous, який за визначенням Collins Dictionary має сучасне значення "еxtremely odious» [51].

"... and he found himself swaying to infandous rhythms said to pertain to the blackest ceremonies of the Sabbat..." [5].

"...і він спійлав себе на толу, шо розгойдуеться $і$ відбиває такт під блюзнірські ритми найнечестивіших ритуалів шабашу..." [2].

Таким чином, у досліджених творах Г. Лавкрафрта нами було виявлено чимало власне лексичних архаїзмів, однак у процесі перекладу атмосфера, створювана ними, вбільшості втрачається через нівелювання архаїчного значення i заміну його на нейтральне.

Лексико-словотворчим архаїзмам у сучасній англійській літературній мові відповідають назви 3 тим самим коренем, але $з$ іншими судіксами і предріксами.

Так, наприклад, в оповіданні The Call of Cthulhu нами було виділено наступні лексикословотворчі архаїзми:

- застаріла форма прикметника subterrene, форма, яка зараз використовується, має суфікс -anean-subterranean:

"...with a subterrene voice or intelligence shouting monotonously in enigmatical senseimpacts uninscribable save as gibberish" [5].

"...з потойбічнил голосол чи розулол, який монотонно бубонів загадкову, пригололшливу, невиловну тарабаршину" [2].

Значення цього архаїзму у перекладі дещо змодульоване і модернізоване, оскільки передане словом, яке краще відбивае атмосферу твору: потойбічнил.

- фрранцузьке написання Esquimaux сучасного англійського Eskimo:

"It was a faith of which other Esquimaux knew little, and which they mentioned only with shudders..." [5].

"Це було вірування, про яке салі ескілиоси знали небагато $і$ на згадку про яке їх кидало у дрож..." [2].

Бачимо, що у перекладі неможливо передати особливості застарілого написання, яке знівельоване перекладачем.

- застаріла форма fungous сучасного слова fungal, в якій спостерігаємо заміну суфікса -ous на -al:

"...a depression which every malformed tree and every fungous islet combined to create" [5].

«кою дихало кожне потворне дерево $і$ кожний вкритий лишайникали пагорок" [2].

Перекладач застосував модуляцію, замінивши буквальний переклад грибний на вкритий лишайникали. При цьому особливості застарілого написання знову знівельовані.

Також у повісті Whisperer in the Darkness зустрічаємо архаїзм morrow замість сучасного morning (заміна суфікса -ow на -ing):

"After what he had told, I could scarcely imagine what profounder secrets he was saving for the morrow" [5].

«Після всього почутого я міг тільки здогадуватися, які ше важливі таєлниці він лишив на завтра" [2]. 
Як і у реченнях вище, перекладач нівелюе архаїчне написання, передаючи його нейтральним словом завтра.

Сучасна лексема between двічі передаеться застарілою betwixt із судіксом -ixt:

"He was wholly bewildered as to the relation betwixt dream and reality in all his experiences" [5]

"Після усього пережитого навряд чи він був спроможний відрізнити видіння від реальності» [2].

Таким чином, у проаналізованих творах $\Gamma$. Лавкрадрта переважною відмінністю лексикословотворчих архаїзмів їх від сучасних відповідників е вживання інакшого суфіксу. Однак, у процесі перекладу архаїчний відтінок їхнього написання повністю знівельований і замінений нейтральними словами.

Лексико-фонетичні архаїзми мають дещо інакше звукове оформлення кореня або закінчення порівняно із сучасною літературною мовою. Нами вибрано лише 1 приклад, але у 28 слововживаннях - застаріла лексема shew(ed), замість сучасного show(ed). Цікаво відмітити, що саме в такій формі цей лексико-фонетичний архаїзм вжито автором в усіх його проаналізованих творах. Наведемо приклади з одного з них (Whisperer in the Darkness (9):

"The clerk shewed him the original text as scrawled in pencil by the sender, but the handwriting was wholly unfamiliar" [5].

"Поштовий службовець показав йому нашкрябаний олівцем оригінал тексту телеграми, однак почерк був зовсім незнайомий» [2].

Отже, бачимо, що лексико-фонетичний архаїзм shew є доволі поширеним в творчості Г. Лавкрафта і присутній в усіх досліджених творах. У тексті перекладу, однак, його архаїчний характер нейтралізовано.

Лексико-семантичні архаїзми у своїй семантичній структурі містять як активно вживані в сучасній англійській літературній мові значення, так і застарілі. Так, в оповіданні The Call of Cthulhu ми виявили лексико-семантичний архаїзм pariah - napiя, який, за словником Collins Dictionary, має сучасне значення "a social outcast" та застаріле - "a member of a low caste in S India" [4].

"It ... disclosed an astonishing degree of cosmic imagination among such halfcastes and pariahs as might be expected to possess it» [5].

«...делонструючи вражаючий рівень неймовірної фбантазї серед таких занехаяних культів $i$ лмаргіналів, яким найленшою мірою можна було б приписати щось подібне» [2].

По контексту ж бачимо, що в реченні вжито перше словникове значення: сучасне (вигнанець), а не застаріле (парія). Перекладач використав техніку модернізації архаїзму, передавши його сучасним поняттям ларгінал.

Повість The Dunwich Horror містить два приклади семантичних архаїзмів:

"Mr. Hoadley disappeared soon after delivering this sermon; but the text, printed in Springfield, is still extant» [5].

«Виголосивщи проповідь, пан Гоудлі незабарол зник, але ї̈ текст, надрукований у Спрінгфбілді, залишився дотепер» [2].
Наявні наступні значення ціеі лексеми: "1. if something is extant, it is still in existence, in spite of being very old. 2. archaic standing out; protruding" [51].

3 тексту оригіналу і перекладу стае очевидним, що використано сучасне, а не архаїчне значення.

"...drawing upon the fullest resources of his own library, and wading night after night amidst the arcana of ... Davys' and Thicknesse's eighteenthcentury treatises..." [5].

«...перевернувши догори дритол свою бібліотеку, просиджуючи ніч за ніччю серед таїн ... датованих вісілнадиятил сторіччял трактатів Дейвіса та Тікнесі...” [2].

Словник подає також 2 значення виділеної лексеми: «1. a formal work on a subject, esp one that deals systematically with its principles and conclusions; 2. an obsolete word for narrative» [4].

3 наведеного у реченні довгого переліку назв робіт, які вивчав герой повісті протягом серпня, можемо логічно стверджувати, що автором знову використане перше словникове значення трактат, наукова робота, що і було відтворено у перекладі.

Повість Whisperer in the Darkness налічуе 8 семантичних архаїзмів. Розглянемо структуру їхніх значень:

«...I have seen things like them under circumstances I dread to repeat» [5].

"...але бачив подібних до них створінь за таких обставин, про які сам побоююсь розповідаmu» [2].

Словник подае наступні три значення, одне $з$ яких е архаїчним: "1. to anticipate with apprehension or terror; 2 . to fear greatly; 3 . archaic to be in awe ofi [4].

Оскільки в реченні згадані певні обставини, що вже відбулися (have seen things like them under circumstances), логічно припустити, що автором вжите саме архаїчне значення to be in awe of, оскільки перші два націлені на теперішній або майбутній час. Перекладачем, однак, пом'якшене значення ціеї лексеми і знову застосовано нівелювання.

"The things come from another planet, being able to live in interstellar space and fly through it on clumsy, powerful wings which have a way of resisting the ether..." [5].

"Ці створіння прийшли з іншої планети; вони здатні існувати в міжзоряному просторі та літати в ньому на незграбних, але потужних крилах, що можуть долати спротив eтеру..." [2].

Семантика виділеної лексеми налічуе аж 5 значень, два 3 них е хімічними термінами: "1. Also called: diethyl ether, ethyl ether, ethoxyethane a colourless volatile highly flammable liquid with a characteristic sweetish odour, made by the reaction of sulphuric acid with ethanol: used as a solvent and anaesthetic. Formula: $\mathrm{C}_{2} \mathrm{H}_{5} \mathrm{OC}_{2} \mathrm{H}_{5}$. 2. any of a class of organic compounds with the general formula $R O R^{\prime}$ where $R$ and $R^{\prime}$ are alkyl groups, as in diethyl ether $\mathrm{C}_{2} \mathrm{H}_{5} \mathrm{OC}_{2} \mathrm{H}_{5}$ " [5]; № 3 - гіпотетична субстанція, яка, як вважалось колись, заповнюе увесь космічний простір; "4. Greek mythology the upper regions of the atmosphere; clear sky or heaven"; 5. "a rare word for air" [4]. 
Оскільки в реченні згадано космічний переліт (in interstellar space), визначаємо, що автором використано трете, застаріле, значення субстанції, що наповнює космічний простір, втім, перекладач вжив спосіб транслітерації.

Нам також трапився приклад вживання інтернаціонального слова «міріади». Розглянемо його:

"There were myriads of claw-prints in the road, with the human prints of Walter Brown among them" [5].

"На дорозі були численні сліди кігтів, а серед них - сліди Волтера Брауна» [2].

Цей іменник може означати як велику невизначену кількість, так і давне поняття у 10 000: "1. (also used in plural) a large indefinite number; 2. archaic ten thousand» [4].

За закінченням множини і визначаємо, що вжито перше значення - невизначена велика кількість (відбитків кігтів). Традиційно перекладачем застосоване нівелювання архаїчного значення.

Наступним прикладом слугуе лексема plethora. Розглянемо також їі словникові значення: "1. superfluity or excess; overabundance; 2. pathology obsolete a condition caused by dilation of superficial blood vessels, characterized esp by a reddish face» [4].

"...marks which stood out blasphemously among the surprising plethora of blurred footprints leading to and from the Akeley farmhouse» [5].

"...три сліди, шо по-блюзнірськолу виділялися серед дивного плетива відбитків, які полережили стежку до будинку Ейкелі» [2].

Оскільки у реченні йдеться не про медичний стан організму, а про кількість відбитків на землі, то вважаємо, що використане не застаріле, а сучасне значення - superfluity or excess; overabundance. Текст перекладу демонструє модуляцію значення: plethora - плетиво.

Щодо до розгляду лексеми or $\boldsymbol{b}$, вона також $€$ семантичним архаїзмом, оскільки поєднуе сучасні та архаїчні значення у своїй структурі:

"1. (in royal regalia) an ornamental sphere surmounted by a cross, representing the power of a sovereign; 2. a sphere; globe; 3. poetic another word for; 4. obsolete or poetic a. a celestial body, esp the earth or sun; b. the orbit of a celestial body; 5 . an archaic word for circle" [4].

Бачимо, що навіть два зі значень є застарілими: "4. obsolete or poetic a. a celestial body, esp the earth or sun; b. the orbit of a celestial body; 5 . an archaic word for circle». Наведемо приклад вживання цієї лексеми у реченні:

"It is a strange dark orb at the very rim of our solar system - unknown to earthly astronomers as yet" [5].

"Це таєлнича телна куля на салолу краю Сонячної систели, досі невідола нашим астронолали" [2].

Проаналізувавши речення, бачимо, що в ньому реалізуеться саме одне 3 архаїчних значень: a celestial body - небесне тіло, що знаходиться на краю сонячної системи, вкотре проігнороване перекладачам.

Першим у словниковій статті знаходиться архаїчне значення наступної лексеми - erstwhile.

"1. Archaic some time ago; formerly 2. of an earlier time; former» [4]. "...one the crude speech of an unknown and evidently rustic man, and the other the suave Bostonian tones of my erstwhile guide Noyes» [5].

"...грубий голос якогось незнайомия, певно, місцевого; а в друголу я упізнав м'яку бостонську вилову лого провідника - Нойєса" [2].

Проаналізувавши речення, що містить цю лексему, бачимо, що реалізується знову сучасне, а не архаїчне значення - former (guide). Перекладачем же застосовано прийом вилучення, оскільки жодних еквівалентів ціеї лексеми у тексті перекладу не спостерігаємо.

10 разів у дослідженому творі зустрічається семантичний архаїзм conjecture, наприклад:

"Certain conjectures were inevitable, but amidst the obvious crisis he did not stop to elaborate upon them" [5].

«Висновки напрошувалися салі, але попри вочевидь критичне становище, Ейкелі не став ïx робити» [2].

"...the muddy, furniture-like prints came to be mixed with his in the garret chamber, were wholly beyond conjecture" [5].

"...з'явилися брудні "відбитки ніжок" - усі иі питання лишалися без відповіді» [2].

Він уміщуе настіпні семи: "1. the formation of conclusions from incomplete evidence; guess; 2. the inference or conclusion so formed; 3. obsolete interpretation of occult signs" [4].

Як бачимо, перша 3 них позначає процес формування висновків, друга - самі висновки, i третя, власне архаїчне значення, відноситься до тлумачення окультних символів.

Так, з прикладів бачимо, що висновки ще не сорормовані, над ними ще потрібно працювати (elaborate), тобто реалізуеться перше значення the formation of conclusions (хоча перекладач вжив слово "висновки», а в другому прикладі використав модуляцію - питання лишалися без відповіді);

Останнім лексико-семантичним архаїзмом, вибраним нами для аналізу з творчості Г. Лавкрафта, став vestige, який має наступний набір значень у словнику:

"1. a mark, trace, or visible evidence of something that is no longer present or in existence; 2 . a surviving evidence or remainder of some condition, practice, religion, etc; 3. a very slight trace or amount of something; 4. Biology a degenerate or imperfectly developed organ or structure that has little or no utility, but that in an earlier stage of the individual or in preceding evolutionary forms of the organism performed a useful function; 5. archaic a footprint; track» [4].

Розглянемо, яке 3 них реалізуеться у реченні нижче:

"When Gilman climbed up a ladder to the cobwebbed level loft above the rest of the attic he found vestiges of a bygone aperture...» [5].

"Коли Дюиллен видерся драбиною на затягнуту густил павутиннял частину горища з рівною підлогою, у стіні над входол до своєї кілнати він знайшов суллінно забиту пройлу..." [2].

Вважаємо, що в ньому реалізовано перше значення зі словникової статті: «1. a mark, trace, or visible evidence of something that is no longer present or in existence" - видимі докази чогось,що більше не існує. На це додатково вказує слово- 
сполучення «a bygone aperture» - колишній oтвір, тобто такий, що більше не існує. У тексті перекладу дана лексема опущена, тобто використаний прийом вилучення.

Отже, нами проаналізовано 12 лексико-семантичних архаїзмів у 16 слововживаннях. Ми виявили, що 8 з них реалізують свої сучасні значення, а 4 - архаїчні. Тобто проявилася лише третина архаїчних значень (33\%), решта значень е сучасними.

У більшості лексико-семантичні архаїзми перекладені прийомом нівелювання 3 поодинокими випадками вилучення.

Висновки і пропозиції. Отже, у досліджених творах Г. Лавкрафрта переважають історизми 3 групи назв зниклих народів, в більшості назв племен північно-американських індіанців, які слугують історичним тлом для написання оповідання або повісті. Також нами було виявлено невелика кількість власне лексичних та лексикословотворчих архаӥзлів, переважною відмінністю останніх від сучасних відповідників є вживання інакшого суфіксу. Нами вибрано лише 1 приклад лексико-ббонетичних архаїзмі, які мають дещо інакше звукове оформлення кореня порівняно із сучасною літературною мовою. Ми також виявили, що більшість лексико-селантичних архаӥзлів реалізують у досліджуваних творах свої сучасні значення, а лише третина - архаїчні.

Перспективами подальших досліджень може стати дослідження архаїчної лексики в інших творах письменника, або порівняльний аналіз вживання архаїзмів у доробку Г. Лавкрафрта та його натхненника Е. По.

\section{Список літератури:}

1. Білодід І.К. Сучасна українська літературна мова. Київ : Наукова думка, 1973. 438 с.

2. Говард Лавкрафот. Повне зібрання прозових творів (пер. Остап Українець). Видавництво Жупанського. 2020. URL: https://www.yakaboo.ua/ua/povne-zibrannja-prozovih-tvoriv (дата звернення: 20.06.2021).

3. Словопедія. URL: http://slovopedia.org.ua (дата звернення: 24.06.2021).

4. Collins Dictionary. URL: https://www.collinsdictionary.com (дата звернення: 24.06.2021).

5. Lovecraft H.P. The Complete Fiction. A to Z Classics. 2014. 728 p.

\section{References:}

1. Bilodid I.K. (1973) Suchasna ukrainska literaturna mova [Modern literary Ukrainian]. Kyiv: Naukova dumka.

2. Howard Lovecraft (2020) Povne zibrannia prozovykh tvoriv (per. Ostap Ukrainets) [Full collection of works in prose (trans. by Ostap Ukrainets)]. Vydavnytstvo Zhupanskoho. Available at: https://www.yakaboo.ua/ua/povnezibrannja-prozovih-tvoriv (accessed 20 June 2021).

3. Slovopediia [Slovopedia]. Available at: http://slovopedia.org.ua (accessed 24 June 2021).

4. Collins Dictionary. Available at: https://www.collinsdictionary.com (accessed 24 June 2021).

5. Lovecraft H.P. (2014) The Complete Fiction. A to Z Classics, 728 p. 